\title{
Nephrotic syndrome presenting in a patient with primary Sjögren's syndrome: questions
}

\author{
Rebecca Ruebner • Pierre Russo • Bernard S. Kaplan
}

Received: 8 August 2011 /Revised: 19 September 2011 /Accepted: 20 September 2011 /Published online: 29 October 2011

(C) IPNA 2011

Keywords Nephrotic syndrome·Sjögren's syndrome

\section{Case summary}

A 17 year-old African American woman with a history of Sjögren's syndrome presented with several days of periorbital and pedal edema. She also had fatigue, headache, abdominal pain, and diffuse arthralgias. She had no gross hematuria or oliguria. There were no recent sore throats or upper respiratory tract infections. She had no weight loss, night sweats, joint swelling, oral ulcerations, or rash. She had taken several doses of ibuprofen for arthralgias but was not taking any other medications. She was diagnosed with primary Sjögren's syndrome at 11 years of age after presenting with bilateral parotitis. The diagnosis of Sjögren's syndrome was based on the parotitis and a history of xerostomia and xerophthalmia. Schirmer's test was abnormal (prolonged wetting time of filter paper placed in the lower eyelid), indicating abnormal tear production. Sialometry showed inadequate saliva production. Serologic markers at the time of diagnosis of Sjögren's syndrome

Answers to these questions can be found at http://dx.doi.org/10.1007/ s00467-011-2033-4

R. Ruebner $(\bowtie) \cdot$ B. S. Kaplan

Division of Nephrology, The Children's Hospital of Philadelphia,

34th Street and Civic Center Blvd,

Philadelphia, PA 19104, USA

e-mail: ruebnerr@email.chop.edu

P. Russo

Department of Pathology and Laboratory Medicine,

The Children's Hospital of Philadelphia,

Philadelphia, PA, USA included normal serum $\mathrm{C} 3$ and $\mathrm{C} 4$, elevated antinuclear antibodies (ANA) of 1:2560, elevated anti-Ro/SSA antibody, negative anti-double-stranded DNA antibody, and elevated rheumatoid factor. She had a normal serum creatinine concentration of $0.7 \mathrm{mg} / \mathrm{dl}$ and a normal urinalysis with no blood or protein. She was treated with prednisone for 1 year and remained symptom free aside from intermittent mild xerostomia and xerophthalmia. Her father has systemic lupus erythematosus (SLE) and lupus nephritis.

On physical examination, she had a normal blood pressure of 108/60 $\mathrm{mmHg}$ and anasarca. She had no parotid enlargement, lymphadenopathy, arthritis, or rash. Laboratory studies were: urinalysis $25-50$ white blood cells per high-power field (HPF) with negative leukocyte esterase and nitrites, 4+ proteinuria, and 0-2 red blood cells/HPF with no red blood cell casts; 24-h urine protein excretion was $3.3 \mathrm{~g}$. White blood cell count was $5,000 / \mu \mathrm{l}$, hemoglobin $12.4 \mathrm{~g} / \mathrm{dl}$, hematocrit $37.3 \%$, and platelets $401,000 / \mu \mathrm{l}$; serum concentrations of sodium were $129 \mathrm{mmol} / \mathrm{l}$, potassium $5.3 \mathrm{mmol} / \mathrm{l}$, bicarbonate $25 \mathrm{mmol} / \mathrm{l}$, urea nitrogen $32 \mathrm{mg} / \mathrm{dl}$, creatinine $1.7 \mathrm{mg} / \mathrm{dl}$, albumin $1.9 \mathrm{~g} / \mathrm{dl}$, and total cholesterol $199 \mathrm{mg} / \mathrm{dl}$. A chest radiograph showed a small left pleural effusion but no mediastinal enlargement.

\section{Questions}

1. What diseases should be considered in the differential diagnosis of this clinical picture? What glomerulopathies would you consider?

2. What additional tests would you obtain, and how would you confirm the diagnosis?

3. How would you manage this patient? 